\title{
The Jewish Verfassung, the Israeli nomos: the constitutional situation of the beginnings of the State of Israel in the context of Carl Schmitt's political and legal philosophy
}

\author{
Wojciech Engelking* (D) \\ Faculty of Law and Administration, University of Warsaw, Warsaw, Poland \\ ${ }^{\star}$ Corresponding author. E-mail: w.engelking@wpia.uw.edu.pl
}

\begin{abstract}
The paper is an attempt to examine how Carl Schmitt's constitutional theory can be useful to analyse the Constitution of the State of Israel designed in the late 1940s - the impact of which Jacob Taubes once certified. The author analyses three projects created then by Leo Kohn through the prism of Schmitt's concept of Verfassung and Verfassungsgesetz. He also reads in the context of Schmitt's philosophy (from Constitutional Theory and The Nomos of the Earth) the constitutional situation of Israel as a country where, first, the Constitution has not been passed and the basic matter of its legal system is regulated by the Basic Laws; second, citizens of Arab origin are excluded from the national community; and third, the borders of the state remain fluid and change due to the constant partition of the land.
\end{abstract}

Keywords: Carl Schmitt; Leo Kohn; Verfassung; Israel; constitutionalism

\section{Introduction}

In 1949, Jacob Taubes came to Jerusalem as a research fellow of the Hebrew University. There he was to conduct a series of lectures on seventeenth-century philosophy. In order to complete one of them, he went to the library on Mount Skopus and, not counting on success, asked for a copy of Carl Schmitt's Constitutional Theory. As it turned out, this 1928 textbook was available in Jerusalem for surprising reasons. Taubes explained a few years later:

'[T]he minister of justice, Pinchas Rosen, needed Schmitt's Verfassungslehre so that he could deal with some difficult problems in the drafting of the constitution for the State of Israel. ... I must admit to being more bemused than taken with the idea that the constitution of the State of Israel ... would be drafted using Schmitt's Verfassungslehre as a guide.' (Taubes, 2013, p. 47)

Indeed, one must agree that the idea that Schmitt's work would inspire the Constitution of the Jewish state is surprising - for three reasons: two direct and one indirect.

The first direct reason is the attitude that Schmitt harboured towards Jews. Schmitt was an anti-Semite not only during his short career of 'the crown jurist of the Third Reich', when he organised such events as the 1936 conference on Judaism in Legal Sciences. Despite his personal relations with many Jews, he fought against them before 1933, in both his public and private writings and actions. In his early work Schattenrisse, he had already written in an anti-Semitic tone about such figures of Jewish origin in the German public life as Walter Rathenau, Ewald Oskar Kohn and Fritz Mauthner. It is also important how easily the ideas contained in Political Theology were supplemented

(C) The Author(s), 2021. Published by Cambridge University Press. This is an Open Access article, distributed under the terms of the Creative Commons Attribution licence (https://creativecommons.org/licenses/by/4.0/), which permits unrestricted re-use, distribution, and reproduction in any medium, provided the original work is properly cited. 
with anti-Semitic components in editions published after the Nazis' rise to power (Gross, 2016, pp. 36, $43,45,73-74)$. As for private writings, in Glossarium, the quasi-journal published after Schmitt's death and written between 1947 and 1951, he explicitly wrote about Jews as 'real enemies' (Schmitt, 1992, p. 18). It is also worth mentioning that some of Schmitt's professional actions had an anti-Semitic background, when he used Nazi politics towards Jews to benefit his own career, such as when he was the only employee of the School of Law at the University of Cologne who did not sign a letter of support to Hans Kelsen, fired because of his Jewish origins in 1934 - what makes this fact even more significant is that, before Nazis came to power, Schmitt had openly offered Kelsen his friendship (Hathaway and Shapiro, 2017, pp. 234-235). And although, as Petr Slováček concludes, Schmitt's anti-Semitism had no biological basis - unlike the anti-Semitism of the Nazis - it was indeed anti-Semitism (Slováček, 2015, p. 17).

The second reason is the attitude of the Jews towards the philosopher from Plettenberg, especially after he took the side of Adolf Hitler's supporters in the early years of the rule of NSDAP. The aforementioned Jacob Taubes, although he considered himself a friend of Schmitt's, wrote about him that he was 'a Christian ... who looked enviously upon those who are Israelites' (Taubes, 2013, p. 28). Nicolaus Sombart considered Schmitt a 'structural anti-Semite' (Sombart, 1997, p. 107) and Karl Loewenstein pointed out as early as 1936 that this 'prominent constitutionalist of the Weimar Republic is today at the forefront of those who defend the regime' (Loewenstein, 1936, p. 813). Even Schmitt's post-1933 personal contacts with Germans of Jewish origin were fraught with reluctance: Georg Eisler only reconciled with him when they were both of old age (Mehring, 2014, p. 114).

The third, indirect reason to be surprised by the passage quoted above is the fact that it was followed up neither by Schmitt scholars nor by Israeli constitutional-law theorists or historians. Although Taubes's collection of texts about Schmitt was published in German in 1987 (in English in 2013), only Jan-Werner Müller and Massimo Cacciari have since mentioned that Schmitt could have inspired the process of writing the Israeli Constitution (Müller, 2003, p. 59; Cacciari, 2009, p. 240). However, no Schmitt scholar or Israeli constitutional-law specialist has examined to what extent the remark made by Taubes neither is purely extraneous nor can be inspiring and bring a new topic to studies on Schmitt as the birth of the State of Israel (as for the latter, with the exception of Hassan Jabareen, with whom I argue in the fifth section of this paper, and Emanuele Ottolenghi, who, however, uses Schmitt to write about the different topic).

Although I find this omission in studies on Schmitt and/or Israel surprising, it also can be considered obvious: there is no evidence other than a quote from Taubes that Schmitt had an impact on Israeli constitutionalism. One may then ask: why consider the topic of the relationship between the German jurist and this state at all and, if one wishes to consider it, how should they do it?

I will answer the second question first. The most obvious option is to make a thesis that Taubes's remark, being the only evidence of Schmitt's influence on the Israeli Constitution-drafting process, is also sufficient. In other words - try to prove that Schmitt was Pinchas Rosen's guide in the process of drafting the Constitution. As for the premises in favour of this hypothesis, it should be noted that, as Assaf Likhovski writes, the knowledge about the impact of pre-war German law on Israeli law is common (Likhovski, 2018, p. 237). The German origin of many Israeli jurists (in this case Supreme Court judges) is also indicated by Fania Oz-Salzberger and Eli Salzberger, who write that 'anyone acquainted with the history of Israel's formative years would know that the German presence on the Court ... is significant and indeed amazing' (Oz-Salzberger and Salzberger, 2000, pp. 81, 89). Pinchas Rosen, born Felix Rosenblüth, surrounded himself precisely with Israelis of German origin, called 'Yekkes' in Hebrew; Uri Yadin, born Rudolf Heinsheimer, a graduate of the University of Berlin, and Haim Cohn, born Herman, a graduate of the University of Munich - two academic centres at which Schmitt's thought was known.

Two counter-arguments can be made for not analysing the relationship between Schmitt and the State of Israel in the way that I proposed in the first option. First, although Schmitt was not an anonymous intellectual in pre-war Germany, his ideas did not have as many supporters as Kelsen's or Jellinek's theories; therefore, if there was a German lawyer who had impact on Rosen, it is doubtful 
that it was Schmitt. Second, in the matter of Rosen himself, Taubes overestimates his role in the late 1940s. Although he was in fact the Israeli minister of justice at the time, he was not personally drafting the Constitution; he commissioned drafts from such lawyers as Uriel Reichmann, Mordechai Beham, Zerach Warhaftig and Leo Kohn (Radzyner, 2010, p. 3). Among the drafts that were then submitted to the Constitutional Committee, Kohn's should be considered the most important: Emanuel Rackman points out that its three versions were discussed in 1948, just before Taubes found Constitutional Theory on Mount Skopus (Rackman, 1955, p. 37).

With counter-arguments that strong, I consider the examination of Schmitt's direct influence on Israeli constitutionalism impossible. It should be added, however, that the same is the case with many other considered-to-be-Schmitt's influences on modern law-making, such as laws enacted in the US after $9 / 11$ or laws concerning the Polish Constitutional Tribunal. For obvious historical reasons, Schmitt's writings were not presented by the legislators as an inspiration to them - and American and Polish laws were enacted several decades after Schmitt's death. Nevertheless, by many researchers, they are considered Schmittian - that is, to be read through the framework that Schmitt's thought provides, as proposed by Adrian Vermuele (2009). It seems probable that, in Israel in the 1940s, presenting to the public a Nazi Party member as a theoretician, whose works were important in the process of law-making, was even more problematic than today - which does not exclude an option to read Israeli legal documents from that time in the way Vermuele did with the American administrative law. This kind of reading is the second option for considering the relationship between the German jurist and the State of Israel, and the one that I will follow.

There is yet another question to be answered: why one should do it? The answer consists of two parts. First, although Israel was put into many frameworks of legal and political thought - majoritarian democracy, ethnic democracy (I analyse them at the beginning of section 5) - all of them keep the version of liberal democracy that was born after the Cold War in Europe and America as a point of reference. Using Schmitt's thought to analyse the birth of the State of Israel then provides the researcher with the framework that is important for two reasons: first - it was part of the intellectual discourse when the state was born; second - Schmitt's ideas are not the ones according to which what is not liberal democracy should be considered problematic. Second, reading early Israeli law-making through the Schmittian framework is also useful in answering questions about the latter. Therefore, I consider using Schmitt's thought as methodology and Israeli law-making from the late 1940s as a topic to be analysed through an interesting intellectual proposition.

This paper consists of six parts. In the second, I will present the constitutional theory developed by Schmitt in Verfassungslehre. In the third, I will present the Israeli dispute from the late 1940s on the topic of whether the Israeli Constitution should be written and provide examples of how Schmitt's theory can be useful in discussing it. In section 4, I will read the drafts of the Israeli Constitution through the prism of Schmitt's theory. I chose three drafts developed by Leo Kohn because, as I stated above after Rackman, if Schmitt was actually to have had any influence on the drafting process, it would have been on Kohn's drafts. Then, in section 5, I will discuss the legal and political status of the Declaration of Independence. As for the Schmittian framework, I will not only use Constitutional Theory, but also Legality and Legitimacy and The Nomos of the Earth. Before I conclude, I will examine the abdication of the Knesset from the position of the creator of a constitution and the accession of the Supreme Court to that position. My main goal is to provide the following thesis: Schmitt's legal and political philosophy provides the most useful framework within which to describe the constitutional situation of the State of Israel in the 1940s - better than concepts such as ethnic democracy. However, as I will show in the conclusion, the accuracy of this framework ends shortly after that period.

\section{Verfassung and Verfassungsgesetz in Carl Schmitt's thought}

Constitutional Theory from 1928 is a special work in Schmitt's œeuvre for two reasons. First, it is the only textbook that he has written. Second, in Constitutional Theory, either some of the most important threads of his thought intertwined or it signalled ideas that had taken or would take full shape in 
Schmitt's earlier or later works. Despite its textbook character and the philosopher's focus on one legal document, Theory is not free of the basic component of Schmitt's style, which is, according to Jan-Werner Müller, polemism (Müller, 1999, p. 67). What, although important, is the subject of his polemics if, in his political writings, Schmitt made liberalism his main target? In Constitutional Theory, because of its juridical nature, he argued against the trend in legal thinking that he considered a consequence of liberalism in the political sphere. The latter was positivism, especially in its normativist incarnation proposed by Hans Kelsen.

In the Germany of 1928, such a polemic was unique. As Benjamin Schupmann points out, German legal science at that time was deeply permeated with positivism: 'although the two currents in this dispute were characterized as "Positivists" and "anti-Positivists," in reality both currents were broadly speaking Positivist' (Schupmann, 2018, p. 7). There was a consensus among lawyers in Weimar Republic at the time that the character and source of the law should not be sought in the space of nature and transcendence, any sphere in which nature is not strictly legal. This was also the opinion of the authors of the Weimar Constitution of 1919, who wrote it as the most liberal document in Europe at the time. Thus, Schmitt's interpretation of the Constitution went against both the will of its creators and the intellectual fashion of the era (Kennedy, 2005, p. 28).

In Constitutional Theory, Schmitt built his polemic against positivism and normativism as consequences of liberalism on three points of contention. First, he observed that his opponents equated all law with positive law and constitutional law with the written Constitution. Second, he took issue with deriving legal norms from legal norms themselves. Third, Schmitt argued against an interpretation of the Constitution that he thought relativised the latter, made without taking into account the specificity of the nation whose state's existence this document regulated, among other things.

His basic level of argumentation was the consequence of the first observation. According to Schmitt, positivist methodology resulted from the conviction that law in general is synonymous with positive law. Schmitt thought that in positivists' method, law was understood as an autarkic system, closed off from factors that could be the subject of reflection in sociology or political science. Schmitt believed that, as a result, positivists and normativists based the validity of norms on a legal pleonasm: norms are valid because they are part of positive law and were enacted in accordance with positive law. Schmitt wrote:

'They are valid, rather, without regard to qualities like reasonableness, justice, etc. ... The imperative abruptly ends here, and the normative element breaks down. In its place appears the tautology of a raw factualness: something is valid when it is valid and because it is valid. That is "positivism".' (Schmitt, 2008, p. 64)

In such a vision of the legal system, the Constitution becomes a mere written document, the importance of which - that is, the claim that lower-order norms are compatible with it - results from the fact that it has been promulgated by an appropriate body. For Schmitt, in such thinking about the law, two dangers interlinked: first, that the Constitution, which was merely a written law, was indistinguishable from other laws; second, that the state became a total organism, over which laws ruled in an undivided manner: the Gesetzstaat (Herrero, 2015, p. 124).

As opposed to the positivists, Schmitt proposed that the Constitution (Verfassung) and written constitutional law (Verfassungsgesetz) should be separated. While the latter would consist of a set of provisions on important matters of the state, and could be created as a compromise between groups with different interests, the former would constitute the unwritten essence of the state organism, dating back to the time before the Constitution was written. As John McCormick points out, the distinction between the Verfassung and the Verfassungsgesetz should not be regarded as an opposition between the letter of the law and its spirit; this would be an oversimplification, and would go against Schmitt (McCormick, 1999, p. 235). Although the Verfassung is part of the law because it establishes it, it is also transgressive towards it: the question then arises: to what extent it is legal and to what extent political. 
By asking it, we move on to the second level of Schmitt's dispute with positivists and normativists: the problem of norms resulting from norms and Kelsen's theory of the Grundnorm. In Kelsen's pure theory of law, lower-order norms are valid because the authority to establish them results from higherorder norms. Moreover, at the base of the whole system of norms, there is the basic norm, the Grundnorm, from which the authority to create all others can be derived. As Andreas Kalyvas notes, it functions as a logical presupposition of its own validity (Kalyvas, 2008, p. 129). It is, as logical-jurisdictional fiction, contentless and impersonal - a transcendental-logical assumption that prescribes the implementation of norms of the lower order as established in accordance with the authority derived from it. According to Kelsen, the Grundnorm is valid 'because it is presupposed to be valid ... being the supreme reason of validity of the whole legal order' (Kelsen, 2017, p. 118). And although, as Richard Stacey writes, 'it is hard to resist, that ... the validity of the Grundnorm depends on its contingent social acceptance' (Stacey, 2011, p. 78), Hans Kelsen's pure theory of law makes it impossible to acknowledge this acceptance as it is a term from outside of legal science.

Schmitt rejected the concept of the Grundnorm and his concept of the Verfassung was the result of this rejection. According to Schmitt, the Verfassung was not the norm and was not legal in the same way as norms were: coming from before the constitutional order and at the same time establishing it, it could not be. As a source of norms and their character, it remained an expression of political will - the decision on what the legal order should look like. As such, it had its own content that could vary based on who made the decision. He wrote:

'The unity of the German Reich does not rest on these 181 articles and their validity, but rather on the political existence of the German people. The will of the German people, therefore something existential, establishes the unity in political and public law.' (Schmitt, 2008, p. 65)

The fact that the Constitution of the Republic was in force, Schmitt believed, was not due to the fact that it had been put to vote and promulgated in accordance with the law, but due to the political will of the citizens of that state from which the constitutional law emerged. Schmitt understood the Constitution in an ancient way: as the soul of the state. Unlike in constitutional law, it was not subject to change in Schmitt's theory, being a source of such an interpretation of constitutional law that would not relativise the Constitution.

In Schmitt's theory, the relativisation of the Constitution could take place in three ways. The first way was to read each norm contained in the constitutional law as equally important for the state; the second was to consider the Constitution as an axiologically neutral document. Because it was a political decision, said Schmitt, the Constitution as a Verfassung had to adopt axiological foundations, from which it would follow which article of the Verfassungsgesetz weighed more than other. In the Constitution of the Weimar Republic, he added, these foundations were determined by the decision to adopt a democratic system: 'there is a decision for democracy, which the German people reached by virtue of its conscious political existence as a people' (Schmitt, 2008, p. 77). Making this decision especially in newly created states - was not the result of a social contract or even the establishment of the state: it was the state that resulted from the collective decision, and the decision belonged to the field of fact. It could have been an effect of an established way of living in a given territory, but it did not have to be, as it could also mean a new way, on which the collective consensus was clear. It was a decision about this way of living and abrogation of the previous one: 'an articulation - as Jo Eric Murkens writes - of a political way of being ... rooted in a sphere that lies beyond the positive, written constitutional text' (Murkens, 2013, p. 45).

\section{1947-1950: the short and unhappy story of (not) making the Israeli Constitution in the context of the idea of Verfassung}

As Adam Shinar points out, the history of Israeli constitutionalism is unique in comparison to its history in other modern countries. That is due to the fact that 'events that gave rise to Israel's 
constitutional structure did not come about as a result of a constitutional convention, referendum, civic mobilization, or any other deliberate process that characterizes traditional constitution-making' (Shinar, 2013, p. 207). Although Shinar's words refer to the whole history of Israeli constitutionalism from the 1940s to the present day - they best illustrate its initial stage. The newly created state was in a way assigned the task to write its Constitution: in Resolution 181 of the United Nations General Assembly of 29 November 1947 (A/RES/181(II), available at: https://undocp.org/A/RES/181(II) (accessed 20 December 2019)), which recommended the split of the British Mandate into an Arab and a Jewish state, it was stated that each of them should adopt a constitution as a basis for its recognition by the international law, and the Crown's authority over the soon-to-be-former Mandate would end on 15 May 1948 (United Nations General Assembly Resolution 181).

On that day, representatives of the most important Jewish political organisations that comprised the National Council met in Tel Aviv and proclaimed a document known as the Declaration of the Establishment of the State of Israel (or the Declaration of Independence) (1 LSI 7 (1948), available at: https://www.jewishvirtuallibrary.org/the-declaration-of-the-establishment-of-the-state-ofisrael (accessed 20 December 2019)). According to that document, during the transition period (from the end of the Mandate to the beginning of the reign of the new government), the National Council was to act as the Constitutional Assembly, and the creation of public institutions was to take place 'in accordance with a Constitution, to be drawn up by the Constitutional Assembly no later than the first day of October 1948' (Declaration of the Establishment of the State of Israel). As Gideon Sapir, Daphne Barak-Erez and Aharon Barak write, in the Declaration, we can find a three-stage project of adopting of the Constitution. As a first step, the National Council was to act as a temporary legislative body (as such, it adopted the Law and Administration Ordinance of 1948, which normalised the distribution of powers) so that, in the second step, the Constitutional Assembly, tasked with drafting the Constitution, could be composed of citizens' representatives and, at the same time, dissolved. The third step was to conduct elections in a way that would be co-ordinated with the Constitution created by the Assembly: 'With the election of a legislature they conclude - the Provisional Council of State would conclude its task and disperse as well' (Sapir et al., 2013, p. 1).

Nothing went as planned, however. The reason was the war, which turned from a civil war into an Israeli-Arab conflict after the end of the British rule - and the matter of the conflict was the very existence of the state whose Constitution was at stake: 'For the local Arabs [the birth of the State of Israel] was an acknowledgement that they had failed in their efforts to prevent the creation of a Zionist entity' (Bickerton, 2009, p. 9). Thus the process of law-making took place in a climate in which 'hatred and violence overboiled yet again, this time with decisive results' (Schneer, 2016, p. 410) and the new state stood on the verge of being destroyed not very long after its birth. During the warfare, elections to the Constitutional Assembly took place - on 25 January 1949 - and the Assembly met on 14 February. Two days later, having decided that the legislative body of the new state would be called the Knesset, the Assembly declared in the Transition Law that it was called the First Knesset. Notably, not a single word about the Constitution of the newly created state will be found in the Transition Law, not even about the date on which it would be passed (since the previous date, indicated in the Declaration of Independence, was exceeded). The problem was silenced and the law - as Hanna Lerner points out - did not explicitly acknowledge the first Knesset's duty to enact a constitution' (Lerner, 2003, p. 56). The Arab-Israeli war ended two months after the elections, in March of 1949.

Despite the absence that Lerner wrote about, between February and July 1950, in the times of fragile ceasefire (Israelis who lived near the border were still attacked by the Palestinian fedayeen), nine debates on the draft of the Constitution were held in the Knesset in order to finally - as Dan Horowitz and Moshe Lissak put it - decide not to decide on adopting it (Horowitz and Lissak, 1989, p. 172). Instead of making a decision, the Knesset adopted the Harari resolution. According to that, 'the First Knesset assigns to the Constitution, Law and Justice Committee the preparation of a proposed constitution ... The constitution will be made up of chapters, each of which will constitute a separate 
basic law' (Harari proposal, available at: www.knesset.gov.il/description/eng/eng_mimshal_hoka (accessed 21 December 2019)). The Constitutional Assembly was dissolved, and with it its power to create a constitution as the First Knesset did not adopt a single Basic Law.

Although the phrase proposed by Horowitz and Lissak is attractive, it needs to be clarified. The First Knesset, although it did not decide what the Constitution of Israel should look like, made a different decision: on whether or not the Constitution's written version should be adopted, which was the subject of political disputes at the time. After all, as Iddo Porat points out, the basic task of the Constitution as assigned by UN General Assembly Resolution 181 - a condition on which Israel would be recognised as a state in the international arena - was fulfilled without the adoption of the Constitution (Porat, 2017, p. 272). Therefore, a debate arose as to whether the new state needed a constitution, and whether the Constitution as a document that was supposed to reflect the spirit of the nation (as Nahum Nir had stated at the first meeting of the Knesset in 1950) could even be created at that time (Medding, 1990, p. 30).

For the reading of this debate in the context of Schmitt's philosophy, the arguments of opponents to the written Constitution from both secular and religious parties are crucial because they reflect the following problems: can Verfassung be put into text, can it be put into text before its establishment, and - the third problem - what is the Israeli Verfassung?

The opponents of the Constitution from a religious point of view argued that Israel should not be a medinat hok (a state with secular constitutional law), but a medinat halakhah (a state with constitutional law that originated from religion, namely the Torah, although it should be noticed that at the same time they did not opposed secularity in areas such as civil or administrative law). At one of the Knesset's first meetings, Meir Loewenstein of the religious party Agudat Israel stated that there was no place in the State of Israel for a constitution that was created by the people because if its findings contradicted the Torah, it would be unacceptable, and if it was competitive with the Torah, it would be invalid (Lerner, 2003, p. 60). The same or similar views were expressed in the Israeli parliament of that time by parties such as Mizrahi and Ha-Po'El Mizrahi (Rackman, 1955, pp. 15-17). In other words, in the view of religious parties, Jewishness was seen primarily as rooted in the Torah and its law was the law of the Torah.

To use Schmittian terms, the religious opponents of a constitution practised political theology, although in its very radical kind: they did not see political institutions that would be the matter of constitutional arrangements as a secularised version of those which were previously religious but, as religious par excellence, never secularised and were at the same time legal, sacral and political (Schmitt, 2005, p. 85; Vatter, 2021, p. 7). For religious parties then, Verfassung could be written, but not as a completely new document: it has already been written, centuries ago, and it was the Torah itself. The fundamental character of this law - the thing that makes it Verfassung - is featured precisely by the fact that religious opponents did not object to the need for writing the new law that would be civil or administrative: they were opposed to laws that regulate the basic problems of the functioning of the state - those that provide the order of the state.

Let us now turn to the secular opponents. They relied primarily on the argument that the state that the Constitution would normalise had existed for less than two years. Israel was, according to them, not only the biblical land of the Jews, but also a completely new country on the world map - the Altneuland, as Teodor Herzl had entitled his 1902 utopian novel (Hirschl, 2010, p. 8). They agreed that the constitutional law that was in force in the land before 1948 was not adapted to the needs of the citizens of the Jewish state: the former was seen by them not only as imposed on the land that they were living in, but also the one that would make it impossible for the Jews as Israelis to develop. However, the secular opponents were not convinced as to whether they knew what these needs were: who the future Israelis were, would and should be. At the time of the proclamation of the Declaration of Independence, the population of Israel was 600,000 Jews - less than 10 per cent of the representatives of this nation in the world (Troy, 2018, p. 453). According to Zionist ideas, this number was to change due to mass immigration; therefore, when the Mapai party opposed the adoption of the Constitution, it did so (apart from partisan reasons) for all those who would come to Israel in the future, as one of its members said (Lerner, 2003, p. 66). 
But the newcomers were not the only expected future citizens of Israel. According to Michael Walzer, the goal of Zionists was to create a new kind of Hebrew people. One of the tools that was to be used for this was the Israeli integration of masses of Jewish citizens who had so far lived in other countries and had been dependent on their policy or economy: introducing them into productive and creative life, implanting them on the land, integrating them into primary production in agriculture, in industry and handicraft, making the background economically independent' (Walzer, 2016, p. 52). A document such as a written constitution could both help and impede this purpose. On the one hand, as Baruch Kimmerling writes, it could enable the Israelis to build a new ideological hegemony with its own state worship or holidays (Kimmerling, 2001, p. 6). On the other, written and adopted at a time when mass immigration to Israel had not yet taken place, such a document might not have been compatible with the social conditions that followed it and would become - as was raised in the Knesset - the beginning of a cultural war (Kedar, 2019, p. 75). Similar was the point of David Ben Gurion, who feared that 'the ideological and cultural argument regarding the content of the constitution would [become] a Kulturkampf that would divert Israeli society' (Kedar, 2013, p. 1).

To use Schmittian terms, opponents of enacting the written Constitution argued that not only Verfassungsgesetz, but also Verfassung of the new state was still to be established: it was not yet known, because Israel was to be home for different kind of Jews than diaspora ones. Verfassung, the opponents thought, should be forged by the means of social process, which only later should find their explication in legal norms. They stood for the conviction that, even if the Zionists have an idea of a new Israeli Jew in mind, imposing it on new citizens of Israel would be a failure because the Verfassung cannot be octroyed. To read it in the Schmittian framework, for the opponents of enacting the written Constitution, as for Karl Theodor Welcker, 'the octroyed Verfassung was not a Verfassung' (Gerkrath, 2018, p. 132) - even if it was octroyed by the very Constitutional Assembly of the newly created state.

And although the (secular) opponents' point of view finally predominated the debate from the 1940s and 1950s (what led to a long dispute on whether or not Israel has a Constitution), the projects of the Constitution also were made. Read through Schmittian lenses, they show dilemmas that correspond with those discussed during the debate, but for obvious reasons both broaden and narrow down their scale. The first is can Verfassung consist of legal provisions? Second, how much does it derive from the cultural tradition of the country it is regulating? Third, can it be mostly invented, not forged by means of a social process? I will show these dilemmas on Leo Kohn's drafts, examining them as an example of Schmittian thinking about constitutional law.

\section{How Schmittian are Leo Kohn's draft's? Reading three sketches of the Constitution of the State of Israel through the glass of Constitutional Theory and Legality and Legitimacy}

According to Lorraine Weinrib, all Western constitutions created after World War II are united by a 'constitutional conception that transcends the history, cultural heritage and social mores of any particular nation state' (Weinrib, 2006, p. 84). Weinrib calls this concept the objective value order, with values such as the equality of citizens before the law and the prerogative of the judiciary to review legal documents. Together, they create a transnational system of institutions.

I refer to this concept in order to confront it with the third method of the relativisation of the Constitution described by Schmitt: the interpreters' disregard for the national conditions of the country in which a constitution functions. The universalism proposed by Weinrib presupposes that every nation bound together in a state can be normalised in the same way. This means that either the political wills of all nations are similar or a political will can be imposed on the nation. The national character of the drafts of Leo Kohn's drafts of the Israeli Constitution contradicts her concept and makes it necessary to take on different constitutional philosophy to analyse them - and yet, at first glance, it does not have to be Schmittian constitutional philosophy. If, as Tom Segev writes, the Israeli rulers focused on national issues, without taking into account, for example, human rights (Segev, 1986, p. 290), why should we not analyse Kohn's drafts with the concepts so well known as illiberal democracy? 
The first reason was outlined in the introduction. However, there is also the second one, which makes Schmitt's concepts well suited for the drafts of the Constitution of the State of Israel - and derives from the criticism of Schmitt's constitutional philosophy. According to Schmitt's opponents, his ideas were too theoretical in their character. They lacked the possibility to apply them to the state that already exists because their primary point was a new state, emerging from existing political orders, which are not yet captured in the institutional form (Böckenförde, 2017, p. 77). As Eric Voegelin observed, in Constitutional Theory, Schmitt never 'leaves this place [space of ideas rather than practical realization possible in the state which already exists] but remains immanent within its ideal vault' (Voegelin, 1931, p. 97). Therefore, because of what Schmitt's opponents considered to be the flaw in his thinking, the theory of the German jurist appears as the good methodological framework within which to analyse the drafts of the Constitution of the state that was not even five years old when the latter were written, but also consisted of political orders and communities well established before its legal and political birth.

However, Segev's 'national' argument may also weaken the thesis that Schmitt's thought provides a language to analyse the draft constitutions of Israel - after all, he is the foreign jurist, with no legal and philosophical background in Jewish tradition. It should therefore be added that, despite the national character of the generation that ruled Israel in 1948, its representatives were aware that 'the process of constitutional drafting is often one of eclectic bricolage of provisions taken from various systems' (Likhovski, 2018, p. 242). It was Prime Minister David Ben Gurion, who - answering the question of whether the Israeli Constitution should resemble the American one - said that Jews as Israelis should 'profit from the experience of others and borrow laws and procedures from them, provided they match our needs' (Jacobsohn, 1992, p. 95).

There was probably no other lawyer in Israel at that time better to be assigned to that task than Leo Kohn, a graduate of the School of Law at the University of Heidelberg, who throughout his scientific career focused on such documents as the 1922 Irish Constitution and in 1937 even participated in the creation of the new Constitution of that country. Despite this fact, he was not the lawyer chosen by Ben Gurion to draft the Constitution: the prime minister preferred Haim Cohn, but his draft fell through because of pressure from religious Orthodox groups (Strum, 1995, p. 85). Nevertheless, Kohn's drafts were influenced by other states' Basic Laws that Ben Gurion liked. Of course, this was also the case of Werner Frauschteter's and Itamar Freund's drafts (in which we can see the influence of the Weimar Republic Constitution) as well as the one made by Shmul Rolwent, influenced by British law (Lerner, 2003, p. 55). However, none of these drafts has been the subject of such intense debate (carried out between 1947 and 1948 in the Constitutional Committee of the Provisional Council of State) as Kohn's three proposals. The main topic of the debate was how the Constitution should emphasise the Jewish character of Israel while at the same time taking advantage of other states' experiences (Strum, 1995, p. 84).

Kohn submitted three drafts of the Constitution to the Constitutional Committee, originally written in English. The changes between them show how, during the 'the constitutional debate taking place in the fledgling state' (Radzyner, 2012, p. 70), his and the Committee's approach towards what in Schmittian idiolect would be called the Israeli Verfassung changed. If, according to Schmitt's theory,

'just as the concept of the state presupposes the concept of the political, so too does the concept of the constitution presuppose the state. ... the set of provisions laid down in a text called "the constitution", is a "relative concept" which is adopted because of the tendency, under the influence of normativist thinking, to conflate the constitution of a state with a document drafted at a particular moment' (Loughlin, 2017, p. 95)

then the changes between Kohn's three drafts reveal the relinquishment from what is relative and important at the particular moment to concentrate on 'the presence of a people ... and the political existence of that people' (Murkens, 2013, p. 48) as a main feedstock from which to build a fundamental law of Israel. 
Kohn's first proposal can be called more a makeshift draft of the Constitution than the Constitution itself. Written in 1947, it bears traces of clear influence by the Constitutions of Ireland, France and the Weimar Republic (Masri, 2017, pp. 162-163). Its provisional character is emphasised by the fact that Kohn, knowing or presuming the most fundamental pillars of the new state - mainly what is its political system, because he defined Israel as a sovereign, democratic, social republic - he did not know what it would be called. Because of that, in Chapter I, he himself proposed several names (Yehuda, Zion, The Land of Israel, The Western Land of Israel) and even chose Mount Carmel (the Partition Plan did not include Jerusalem as part of a future Jewish state) as the permanent seat of the government (Mahler, 2004, p. 138). In the preamble, he also reiterated the arrangements of UN General Assembly Resolution 181, pointing out that the Constitution will come into force after the proclamation of the state. As for the separation of powers, he divided the executive between the President of the Republic and the Executive Council, appointing the term of office of the former for five years with the possibility of re-election (Kohn, 1954, pp. 2-3). He also mentioned such specified arrangements as the form of detaining a citizen, the military courts and the state's provision of free primary education.

Three aspects of Kohn's first proposal are important to put it in the Schmittian framework. First, it is what was addressed in the draft; second, what was left unaddressed; third, the question of determining when the Constitution was to come into force.

As for the matters addressed, what amazes most in Kohn's first draft is how detailed it is. Kohn not only provides the future state with very specific regulations concerning the broad scope of the matters of the life of its citizens; he also normalises the borders of the political power at great length, such as when he addresses the topic of presidential power. Therefore, his first draft is not a broad description of the way of the functioning of the state - what Schmitt would consider Verfassung - but a detailed one: in other words, what Schmitt would consider constitutional law. Yet, on the other hand, it should be noted that, in terms of general provisions, Kohn clearly defines the political character of the state. He writes that the Jewish state is a social republic, not allowing it to forge its nature itself and/or derive it from the decision of the Jewish people - as, in Schmitt's thought, the imperial and dictatorial way of controlling the state was derived from the character of Germans and was innate to them (Salter, 2012, p. 10). This lack of the forging aspect is also important concerning the most visible omission in Kohn's vision. As Amihai Radzyner writes, in his first draft, Kohn avoided any overt reference to the issue of religion (Radzyner, 2010, p. 7), although he included the explicit statement that the state is home to Jews and did not define Jews in any way: neither as followers of Judaism, nor as people born from Jewish parents. In other words, he did not define the character of the political community whose decision becomes Verfassung. If Schmitt's theory, at its centre, has the 'unified will of a pre-existing people. Schmitt is not concerned with legality ... but only with the factual existence of the state, i.e. the political union of the people' (Murkens, 2013, p. 49), Kohn's draft does not. Also the statement that the Constitution is valid when the state is created takes away its character of Verfassung, according to which it is the political strength of purpose that creates the state: that which cannot be put within the framework of legal terms. However, Kohn's concern on the latter also does not put his draft in place of Schmittian Verfassungsgesetz: by repeating the words of UN Resolution 181, it treats the UN Resolution as a political will imposed on Israel by an institution of international law. Therefore, read through the Schmittian prism, Kohn's first proposal contradicts Schmitt's theory and therefore the framework provided by Schmitt is not proper to read it through.

Kohn's second draft was submitted to the Committee in July 1948, after the announcement of the Israeli Declaration of Independence. It contained far-reaching changes that partly were the result of the circumstances in which the document was created. First of all, Kohn changed what appeared to be the general definition of the political system of the new state to that which was really general: in the second draft, Israel became a sovereign, independent democratic republic (which could become a social one, but this political system was not assigned to it). Second, he did not include the clause from the previous draft according to which the Constitution was to be in effect from the date on which the State of Israel would be granted independence (Kohn, 1954, pp. 8-9). Although practical 
reasons for such an omission are clear (Israel was already an independent country when Kohn submitted the second proposal), we can also put this in Schmittian idiolect, according to which Kohn no longer emphasised the secondary nature of the document that he had written in relation to the political will that constituted the state. Moreover, he pointed out its superiority over the law in force during the transitional period, introducing a provision according to which the former Mandate law would be in force unless it contradicted the Constitution or was repealed by the parliament.

Reading this paragraph through the prism of Schmitt's constitutional philosophy, it can be said that, this time, Kohn placed the document that he wrote in the position of the Verfassung. Positive, constitutional law - understood by the German jurist as 'the multitude of provisions projected in the document promulgated as the Constitution of a state, including the catalogue of constitutional rights' (Gunfello, 2016, p. 95) - would be its derivative, and it would only be valid if it was compatible with the Constitution, even if it had other, normatively understood prerequisites of validity. In a word, if read through the categories of Schmittian methodology, Kohn's second draft appears an expression of the political will of the Israeli community - 'a factual ability to constitute or, in other words, by a factual power or authority that makes the act of constituting possible to begin with' (Minniken, 2020, p. 435) - that was taking over the new state and was not so easy to be closed in legal terms. Even the positivist spirit of section 81 of the second draft (according to which the Constitution would only be in force since its publication) does not contradict the Schmittian framework of constitutional thinking. That is because, after stating the existence of the government as structured by the Law and Administration Ordinance of 1948, Kohn treated the document he wrote as an amplification of the latter. Read through Schmittian lenses, the Ordinance becomes therefore an expression of the political will of the community, presented there in a rudimentary version without covering the entire structure of the state. The tension between Kohn's draft and the Ordinance is therefore not a case of a 'written constitution ... attempt to enforce the legalistic presumptions of liberal constitutionalism ... implicit denial of the political community's power to protect the political expression of what it takes to be its identity as it sees fit' (Vinx, 2013, p. 100). It is only the broadening of the legal but still broad provision of what the constitutional law can cover.

Also another important topic of Schmitt's constitutional philosophy can be found in Kohn's second draft. What according to Schmitt is crucial to the structure of the state is the way of life of the community that the state unites: 'the way in which the concreteness of this constitution proves itself - how, if you like, the 'fact' of a particular way of life is made normatively significant' (Gunfello, 2016, p. 96). As Andrew Norris writes, the German jurist wants to draw out the existential quality of political community by establishing a link between individual human life and the collective way of life (Norris, 1998, p. 73). According to Schmitt, making the way of life a political and legal matter of the Constitution equates to living in a certain manner. As for Kohn's second draft, in its section 15(4), we can find the provision that the Sabbath and Jewish religious holidays were nonworking days. This norm applied in Kohn's intention to all citizens: Judaists and not. This is a significant change from the first draft, in which Kohn adopted the principle of religious freedom and the equality of all religions in Israel. As Amihai Radzyner wrote, it should be treated as a 'symbolic attempt to enhance the position of Jewish tradition in the proposal ... if these and other sources can be identified as influencing Kohn, one source is noticeably absent: the Jewish tradition with all its layers' (Radzyner, 2010, p. 8). Another example of rooting the Israeli Constitution in the Jewish tradition that Radzyner wrote about is the provision of section 12, which regulates the prohibition of the death penalty in Israel because the Talmud forbids it. Although this provision is actually a repetition of the same section from the first draft, its explanation points to Kohn's stronger focus on the Talmud as the source of the Jewish way of living. The second draft similarly regulates the institution of rabbinical courts; although Kohn's first sketches had already assumed their existence, in the next, he clearly indicated their role as present in the Jewish state, although, as he stressed, the law of the latter was not based on a religious one (Kohn, 1954, pp. 12-14).

This provision is on the one hand key to reading Kohn's second draft as the Israeli Verfassung. On the other, one can find its general idea to be the negation of Schmitt's constitutional thinking. 
Let's start with the arguments in favour: Kohn's second draft reveals the idea that the Constitution should be more deeply rooted in the decision on the Israeli way of life - which was not expressed in legal terms, and therefore was political in Schmitt's understanding - than in religion. By this very rooting, Kohn avoided writing the Israeli Constitution as a kind of political theology, and also did not became similar to other Israeli lawyers of that time (Haim Cohn, Moshe Smoira) who believed that Jews 'are a nation with an ancient tradition that they should have pride in and use' (Kedar, 2019, p. 72) in their Constitution - and this ancient tradition is the religious one. His project primarily can be seen as part of, to use the metaphor made by Daniel J. Elazar, the tradition of constitutionalism, in which history and religion are the walls of the house that is the Constitution - but a roof must also be built, thus joining them and creating a new part of the political order of the state (Elazar, 1985, p. 233). However, if, from draft to draft, the paragraphs of Kohn's work are more and more focused on these walls (even by taking up the issue of public holidays) understood as an Israeli way of living, then they do not confirm the fundamental character of the way of living as a political decision. They rather serve in favour of many Zionists' indication that the new Jew should be created in the State of Israel. It is this new, future Israeli Jew, whose way of living is the subject of Kohn's second draft, that makes it problematic to regard Kohn's project as a written form of what Schmitt understand as a 'decision which establishes the existence of a group of people who see themselves as part of a particular cultural form that must be defended' (Pan, 2009, p. 57).

However, in an unexpected way, this very decision became a part of Kohn's third draft, written a few months later. According to Radzyner, the changes made between the latter and the previous were minimal. However, one note makes a particularly strong point of the fully Schmittian character of this document, which I would like to read as a form of existence of the Israeli constitutional law. This is section 11 of the draft, concerning the status of Jerusalem and the Arab citizens, which in its versions in previous drafts was a repetition of Resolution 181 of the UN General Assembly. Then, it had stated that 'the State would settle its disputes in peaceful ways and would refrain from using force to resolve them' (Radzyner, 2010, p. 9). In the third version, it took on a different shape. From now on, Israel only had to try to find a peaceful solution to the situation of Arab citizens and the issue of Jerusalem as a common city (Kohn, 1954, p. 16). This way, using Schmitt's idiolect, the Israeli Verfassung was removed from the space of external imposition and became an expression of the political will of the new state: the decision of the community. If, as Gavin Rae writes, according to Schmitt, the Constitution is

'the concrete, comprehensive decision over the type and form of [community's] own political existence .... Norms are not natural, but are chosen by the populace based on the type of society desired ... each state, as manifested in its constitution, is based in and from the decision of the people regarding its own values' (Rae, 2016, p. 119)

then the provision concerning who will make a decision (derived from these values) about the Israeli territory is, in Schmittian terms, precisely a constitutional decision. The topic of actual space of the new state will return in the next section of this paper, when I will discuss the question of the borders of Israel.

Before I turn to it, I have to stress one more topic. Although the analysis above may seem satisfying and can be considered the useful adaptation of the Schmittian framework to Kohn's drafts, there is another thing to be considered: the question of the usage of legal terms in sketches of the Constitution made in the late 1940s. After all, 'Schmitt argued that political constitutions are, first and foremost, existential rather than written' (Heidepriem, 2020, p. 255). The word 'rather' is important: Schmitt did not state explicitly that Verfassung cannot be written. Despite this fact, to properly put Kohn's drafts into the Schmittian framework and the concept of Verfassung, and thus make the argument of this paper stronger, one must therefore use another concept from German jurist's thought. The latter is the concept of super-legality from Legality and Legitimacy from 1932, which would complement the idea of Verfassung. 
Schmitt's super-legality is a category similar to the set of provisions that Lorraine Weinrib wrote in the quote from which I have started this section, but yet different: a collection of principles that 'every constitution recognizes ... the system of order that should be constituted through the constitution' (Schmitt, 2004, p. 58). In the quoted passus, Schmitt clearly follows his thinking from Constitutional Theory, yet does not call these principles Verfassung or bring in the difference between the latter and Verfassungsgesetz - so, to use other words, he does not consider them only a matter for a political decision, but material for legal principles as well. On the contrary to the provisions that Weinrib wrote about, the provisions of super-legality are not international and universal - at least not in their intent - but remain unique for every constitutional order they constitute. Schmitt is, of course, not a consequent thinker; if we however were to think about how political decisions of Verfassung translate themselves into legal norms - and the translation is not in a fraction so important a political decision as it is a vehicle - we have to say that the effect of this translation is super-legality, therefore, although Kohn's drafts express Verfassung, they express them in the form of super-legality.

Or, it should be said: would express it. Although three drafts are the record of how legal terms have been becoming more general to contain political will as the primary content of Verfassung via superlegality, and therefore what happened in Israel in the late 1940s can be analysed as a process of practical implementation of Schmitt's constitutional theory (not stating that it actually was), it can be only interesting for the legal theorist who does not care about the impact of the topic that he explores on the actual political community (Mahler, 2020, pp. 267-283). Because, as I recalled in the introduction to this paper, none of Kohn's drafts was made an actual constitution; to use Schmitt's idiolect from Constitutional Theory to describe the real legal and political situation of this state in the 1940s and after, one should try to find another legal/political act to which Schmittian categories are suited to describe. The latter is as problematic as Kohn's drafts - although it does not pull the rope between the legal and the political and does not include the concept of super-legality - and in its analysis, the idiolect provided by Schmitt in Constitutional Theory also should be completed with ideas from his later work.

\section{The nomos of the Altneuland: Israeli Declaration of Independence of 15 May 1948 and the appropriation of the new space}

Writing in 1937 about the Constitution that the Jewish state should have, Ze'ev Jabotinsky stated that, in his opinion, it should not contain too many sections that would emphasise the national character of the Jewish state. Although, as a Zionist, Jabotinsky cared about maintaining the national character of the state, he also thought that it should be derived from the space of reality. He wrote:

'The natural and best way is for the "national" character of a state to be guaranteed by the simple fact that it has a specific majority .... When I say the words "Hebrew state", I mean a commonwealth, or land, enjoying a sufficient measure of self-government in its internal and external affairs, which has a Jewish majority.' (Kedar, 2019, p. 79)

The Israeli Declaration of Independence of 15 May 1948 contradicts Jabotinsky's indication. The Jewishness of the emerging state was its main distinguishing feature. In this section, I would like to read it in the same way as I have above read Leo Kohn's drafts: through the prism of Carl Schmitt's philosophy of law and politics. Below, I will therefore analyse the Declaration first as a document containing a direct political distinction between the enemy and the friend and second as an example of basing the law in the nomos rather than the Gesetz. I will use nomos in the same way as I used super-legality in the previous section: as a vehicle for Verfassung, what should be brought out in my polemic also with the Schmittian thesis Hassan Jabareen had put forward about it.

The history of the creation of the Israeli Declaration of Independence was discussed in the third section of this paper; this one is focused on how its authors stressed that the proclaimed state is Jewish. On the one hand, this emphasis only explicitly appears in the document once: 'we, members 
of the People's Council ... hereby declare the establishment of a Jewish state in Eretz-Israel, to be known as the State of Israel' (Declaration of the Establishment of the State of Israel). On the other hand, the historical and legal references that the authors of the Declaration made (first and foremost to the ideas of the Zionist movement, but also to the Balfour Declaration) clearly indicate that the Jewishness of the new country is its main and most valuable component. Israel is not the state of those who hold Israeli citizenship, but it is the Jewish state, as in the title of Herzl's essay from 1896 mentioned above. The problem is that, as Ran Hirschl writes, the founding fathers of Israel did not properly indicate anywhere what this emphasised Jewishness was supposed to mean: participation in Jewish culture, membership of a national community or perhaps adherence to Judaism (Hirschl, 2010, p. 140). The same, as I wrote in the previous section, was the case with one of Kohn's drafts. Differently, however, from Kohn's work, in the Declaration of Independence, we can find what would not be a positive definition of a Jew, but a negative one. To trace it means to check whom the founding fathers of the State of Israel did not include in the Declaration in the historical circumstances of 1948 .

The excluded group, Orit Rozin notes, were primarily Arabs: '[T]here was ... no intention in the Declaration of Independence to include non-Jewish inhabitants of the country in the common identity' (Rozin, 2007, p. 254). (Of course, one should also remember parts of the Declaration that promise full, equal rights to the Arab citizens, and call on them to take part in building the new state as a state for all of its residents; the omission of them by researches of early Israeli history, such as Rozin and Segev, shows these parts however as froth that was never meant to have any political or even symbolic significance.) This - softened by provisions of the Declaration such as ensuring that Arab citizens enjoy equal rights - was reinforced by a passage from Ben Gurion's 1950 letter to the American President Harry S. Truman, in which the prime minister responded to the American claim that Palestinian refugees could return to Israel. Ben Gurion wrote: '[T] here are no refugees - there are fighters, who sought to destroy us' (Segev, 1986, p. 34). Arabs, who comprised almost one-fifth of Israel's population right after the War of Independence, were excluded from such republican national identity-building rituals as service in the army, even if they had received citizenship of the new country, as noted by David Kretzmer (2019, p. 20). Moreover, such legal acts as the Law of Return (passed at the very beginning of Israel's history in 1950) constituted Israel as a state that belongs to 'Jews, both those resident in the country as well as abroad. Even if the Arabs have equal rights on all other levels the implication is clear: Israel is not their state' (Kretzmer, 2019, p. 31).

This kind of treatment of Arabs can provoke the statement that the Declarations as well as the Law of Return introduce a kind of state that can be called ethnocracy. Yoav Peled even claims that Israel is the archetypical ethnic democracy and non-liberal democracy because, after the 1940s, in the absence of a formal Constitution and a Bill of Rights, the state was able to practically suspend most of the rights of its Palestinian citizens that had been granted and to subject them to a harsh system of control (Peled, 2014, pp. 93-152). According to Sammy Smooha, Arabs in Israel were made a low-status minority ... subordinate to Jews in every respect: class, power, prestige, and dominant culture. They are a primarily working-class community in a middle-class society. The average Arab commands fewer competitive resources than the average Jew' (Smooha, 2010, p. 6). And although the interpretation of today's Israel as etnocracy (or even colonial regime) is widespread among the researchers, I consider it a mistake to make it the basis of reading of the Declaration or the Law of Return. As in the case of Kohn's drafts, I believe that Schmitt provides a better framework within which to interpret these two legal documents and their socio-political relevance in Israel at its very beginning on at least two levels: first, the level of ethnicity, second, the level of the borders of the State of Israel.

I will start with ethnicity. Above, I pointed out the remark made by Kretzmer about Arabs' lack of participation in Israeli republican rituals. This occurrence can be easily described using Carl Schmitt's idiolect - although not from Constitutional Theory but from, written at the same time (1927), The Concept of the Political, which can be treated as prolegomena to the concept of Verfassung (Mouffe, 1993, p. 189). Read through Schmitt's theory, the difference between the Jews and the Arabs - in other words: the primary difference that is constituting the state - is not an ethnic 
difference but a political one: biological issues are used as means, not as an end. Rather, what was considered the endgoal here was the construction of an identity for not so much the citizen of the new state (after all, this could also legally have been an Arab) but for a member of a political unity from which the will to form a state arises - the same unity that is the subject of Verfassung. This kind of unity, according to Schmitt, is established in an exceptional situation because it is there that the primary political difference between friend and enemy is revealed:

'The specific political distinction to which political actions and motives can be reduced is that between friend and enemy. This provides a definition in the sense of a criterion and not as an exhaustive definition or one indicative of substantial content. Insofar as it is not derived from other criteria.' (Schmitt, 2007, p. 117)

In a sense, Schmitt follows the path of Kelsen: his methodological postulate is to cleanse political science from the influence of other sciences. However, his goal is different from Kelsen's. Instead of objectivity, he proposes subjectivity, as the relationship between friend and enemy 'can be judged only from the participant perspective ... not from the neutral perspective' (Mehring, 2014, p. 184).

According to Gabriella Slomp, there are two possible dimensions of hostility and friendship in Schmitt's theory. One treats the enemy as an outsider to the community with which the subject identifies himself - in other words: the community normalised with Verfassungsgesetz, a strictly positive legal act - while the other concerns the enemy who belongs to the community (Slomp, 2009, p. 113). The latter is the case of Arabs in the abovementioned legal acts: they are included in the collective framework but excluded from political unity (subject of Verfassung) by being forbidden from participating in such emergency situations as military service. (According to Schmitt, the most radical incarnation of the state of emergency was war.) On the level of representation (e.g. being a member of the Knesset), the Arabs' political status can also be shaped only within a framework of the political in which the axiological content of hostility and friendliness is already established (by prohibiting the denial of the Jewishness of the state). In other words, read through a Schmittian prism, as citizens of Israel, Arabs have no influence on its political order. Their status is although not the status of the ethnic group that is excluded from this order because the order is built on the ethnic difference, as it would be in the ethic democracy: their ethnicity is the means to build this order, but is not a finished construction, and the Declaration shows its temporality.

This temporality is the answer to the second question of Schmittian interpretation of the Declaration of Independence and the Law of Return, which concerns the problem of the borders of the State of Israel. To reach it, however, first we have to ask about the legal status of the document from 1948. According to Suzie Navot, the Declaration shares most of the characteristic points with written constitutions of Western countries: it was issued by an authority that enjoyed pouvoir constituant at that time, it refers to key matters of the state and it meets the conditions set by the Partition Plan for the Constitution (Navot, 2014, p. 12). And yet, its lack of constitutional significance was established as early as 1948 by the Supreme Court of Israel in the Ziv case, in which the plaintiff referred to the Declaration as a set of Israel's basic norms. The Supreme Court rejected this argument, stating that 'the only object of the Declaration was to affirm the fact of the foundation and the establishment of the state for the purpose of its recognition by international law' (Likhovski, 1971, p. 13). One may say that Israeli lawyers of a later time saw the Declaration in other ways: as a foundational document that trumps the rule of law - Justice Agranat in the Yardor case of 1984 - but, being a foundational document, does not equate to the Constitution (Weill, 2012, p. 353). Therefore, the question arises: What is the status of this document - and how can Schmitt constitutional philosophy help in determining it?

According to Hassan Jabareen, not being a constitution, the Declaration serves as the Israeli Verfassung that Kohn's drafts have never become. Reading the Declaration through the prism of Bruce Ackerman's originalism, Jabareen sees it as the moment when a political decision was made that resulted in Israel becoming a state organism. According to Jabareen, this way of thinking about both the Declaration and such acts as the Law of Return is justified because although they 
are law, they also remain transgressive towards it. Rather than on the norm, they rely solely on a political decision regarding reality: on the existential evaluation of reality, as Schmitt would put it. According to Jabareen, along with such acts as Israel as the Nation-State of the Jewish People of 2018, they constitute the Israeli Verfassung:

'The Israeli Constitution is Schmitt's Constitution, as the founding people's identity is itself the state's identity, and thus its democracy is a people's democracy and not its citizens' democracy. Thus, for Israeli Zionists, the "Jewish state" is a "democratic state", as both identities live legitimately together without contradiction.' (Jabareen, 2019, p. 453)

Although very much Schmittian, this approach seems unjustified to me. What Jabareen misses are the issues that I have highlighted in section 3 of this paper, namely the arguments of the opponents of the adoption of the Constitution by Israel as early as the late 1940s. If one were to treat the Declaration of Independence as a Verfassung, one would have to acknowledge that, at the time it was written, there was a coherent political identity of Israelis through which they could express their political will and thus form a state. This approach, however, entails ignoring the fact that the founders of Israel hoped for mass migration that would allow the creation of the new Jew. Thus, according to Jabareen's hypothesis, the political will by which the community makes the decision to be a state could be added years later, within the framework of the formation of the state, and it would have first been considered a meaningless assumption of its own existence. Such an approach contradicts the writings of Schmitt, who was a critic of the concept of a living constitution.

Nevertheless, this does not mean that Schmitt's philosophy lacks a category to describe the Declaration of Independence. That category is nomos, which I would use in the same way as I used super-legality in the previous section: as the vehicle.

In Constitutional Theory, the category of nomos is mentioned only once, when Schmitt argues with James Goldschmidt's usage of the term 'nomocracy' to describe the German Rechstaat: 'That which is directly lacking is the nomos, and the misuse lies in the failure to recognize what remains as a minimum of the traditional rational concept of the legal norm' (Schmitt, 2008, p. 184). Two decades after writing Constitutional Theory, in The Nomos of the Earth, Schmitt gave the answer to the question of what this minimum is. There, he criticised equating the nomos and lex, and the consequence of such an equation in the form of Gesetz. According to Schmitt, the nomos, not being, as Thanos Zartaloudis writes, 'a somewhat philosophical $>>$ Law of law $<<$ ' (Zartaloudis, 2018, p. xxxix) differs from lex because the latter refers to codification under positive law; that is why 'not to lose decisive connection between order and orientation, one should not translate the nomos as law, regulation, norm or any similar expression' (Schmitt, 2006, p. 71). The nomos refers to what is real because it is spatial. Schmitt found its roots in the Greek word nemein to which the nomos is the nomen actionis, the action that is the meaning of the word. Nemein, in which the German words nehmen and Nahme have their roots, means 'to pasture', 'to run a household' and 'to produce'. Therefore, the nomos in Schmitt's understanding - not the original ancient, because, as Zartaloudis writes, 'neither does nómos entail predominantly the sense of a $>>$ division/distribution of land $<<$ in the epics ... Schmitt seems to disregard the fact that only nomós relates expressly to land allotted' (Zartaloudis, 2018, p. 118) - is a political way of structuring a geographical territory, which takes place in three stages: by inhabiting the land (appropriation), later demarcating it from another (division) and finally using it (producing).

According to Claudio Minca and Rory Rowan, the first and second meanings/moments are crucial for Schmitt, because they are identical to the act of violence that occurs in the state of emergency as the state before the creation of a political unity. By separating what belongs to its land from what is not, creating a nomos separates what is the object of the norm from what is not (Minca and Rowan, 2015, p. 275). Nevertheless, the separation is impossible without a conquest, and therefore the 'appropriation of land is law's fundamental constituting act, even when men have forgotten it. In such cases, Schmitt argues, it is legitimate to conjecture that language knows it still' (van der Berge, 2019, p. 205) although this is rather Schmitt's interpretation of this language. 
In the Israeli Declaration of Independence, the issue of the borders of the state is largely neglected. Precisely this makes it possible to describe the Declaration using the Schmittian idiolect as an expression of the Israeli nomos in the two most primary stages: acquiring of the new land and its division. Although the UN Partition Plan specified exactly which territories the newly established Jewish state was to occupy and which territories would be Arab, in the fourteenth point of the Declaration, only the following was written: 'The State of Israel is prepared to cooperate with the agencies and representatives of the United Nations in implementing the resolution of the General Assembly of the 29th November, 1947' (Declaration of the Establishment of the State of Israel). During the meeting of the National Council on 12 May 1948, David Ben Gurion pointed out the political reasons for such a statement:

'We accepted the UN Resolution, but the Arabs did not. ... If we defeat them and capture Western Galilee or territory on both sides of the road to Jerusalem, these areas will become part of the state. Why should we obligate ourselves to accept boundaries that in any case the Arabs don't accept?' (Kleiman, 1999, p. 108)

The borders of the Jewish state were therefore defined as emerging, in the process of military struggle rather than being granted through arrangements resulting from international agreements - and therefore the Jewish reaction to the Partition Plan can be easily interpreted as an answer to Schmitt's question: 'Who is the great appropriator, the great divider and distributor of our planet, the manager and planner of unified world production?' (Schmitt, 2006, p. 360). The answer is: not the international institutions that imposed Israel with the Partition Plan, but the nation, which is acquiring new space, and scarcely marking its borders.

If one tried to place concepts from Constitutional Theory, and in particular the Verfassung, on the concept map for The Nomos of the Earth, they should understand it as corresponding both to the first and second meanings/moments of nomos: the appropriation and division of land. The expression of the political will is the same as the acquiring of new space and demarcating the state organism from others; a community, by establishing itself in a state, also designates a place where it will live. A similar analogy could be made by treating the Law of Return as an element of nomos. In this case, the inflow of Jews from around the globe to Israel would be implicate the seizure of land. They would need living space in this country, and therefore acquire it through new-space conquest. What should be added is that reading the Israeli legal and political situation from the 1940s and 1950s through the prism of the first and second aspects of nomos provides an interpretation from a unique perspective of seeing how what Schmitt wrote about made its realisation in the very same moment, impossible in the other parts of the globe. Schmitt's works from the 1950s (not only The Nomos of the Earth, but also corollaries to this work) are yet filled with the conviction that

'in post-war political thought and practice, land appropriation has ceased to be a condition precedent of a sovereign order. Instead - Patrizia Tuitt writes - political theory would have it that positive legal norms alone can confer upon a polity its constitutive force.' (Tuitt, 2011, p. 177)

The example of Israel shows that appropriation through conquest is still possible in the epoch that, as of seizing, Alexandre Kojève wrote in a letter to Schmitt in 1950s, is irretrievably past (Schmitt and Kojève, 2001, p. 103).

The nomos that is expressed by the Israeli Declaration of Independence is therefore the spatial reality of Israel acquiring new land. This nomos functions as a vehicle for Verfassung - being dynamic and never settled, it is nomos until it grabs new territories. After that, it becomes a political decision that constitutes the community into the form of Verfassungsgesetz - and only after that because, before new land is acquired, no law can arise from it: 'In mythical language the earth became known as the mother of law. This signifies a threefold root of law and justice' (Schmitt, 2006, p. 114). The omitting of the question of the borders of the new state allows it to became a part of the Declaration - in 
other words: to be included because of its' exclusion - which, according to the Israeli Supreme Court from the 1940s, is neither a constitution nor a set of constitutional principles, and therefore remains a strictly political act that Verfassung, as transgressive to the legal and the political, spurts out.

It may seem ironic that, although the statement of the latter institution makes the argument about Verfassung and nomos being the useful framework within which to describe the legal and political situation of the State of Israel in the 1940s and 1950s as stronger, the later activity of the Israeli Supreme Court also limits this framework to the abovementioned period of time. This deserves a separate remark in the conclusion of this paper, to explain why I am constricting my examination only to this epoch, beside some scholar's conviction that Schmitt provides also a framework suited to describing the law-making and politics of Benjamin Netanyahu (Finchelstein, 2019, pp. 175-247).

\section{A remark about judicial activism and conclusion}

'The people as legislator must not be circumscribed,' said David Ben Gurion in 1954 (Ben Gurion, 1954, p. 271). However, the events in Israel did not go as its first prime minister had wanted them to, and the 'judicial review became an important factor in Israeli politics as a result of the efforts of "independent judges"' (Jacobsohn, 1992, p. 96). These efforts, however, were not the only reason why the Supreme Court became one of the strongest political institutions in Israel. It is also a consequence of the fact that, as Adam Shinar writes, the Knesset abdicated from its original role as the Assembly formed to adopt the Israeli Constitution (Shinar, 2013, p. 215). The Supreme Court assumed this role in a specific way. The judges did not attempt to write the Constitution, but they began to decide with their subsequent judgments which Israeli laws could be considered constitutional regulations and what the role of the institution of the Court was in this recognition.

To give just a few examples, in 1969, in the Bergman case - called the Israeli Marbury v. Madison by Robert Burt (1989, pp. 2019-2020) - the Supreme Court of Israel itself recognised its jurisdiction to make judicial reviews. Within this jurisdiction, it decided in 1992 that if the regulations of the Basic Laws conflict with the regulations of regular law, their status does not give them per se superiority over the latter. Three years later, in the Bank Mizrahi case, the judges decided that any law adopted by the Knesset that would restrict the Basic Law of 1992 (Human Dignity and Liberty) was invalid. It was only after this verdict, as Frank Michelman writes, that the doctrine began to universally consider Israeli Basic Laws as constitutional regulation. It can therefore be said that the Court somehow took them to that level, not seizing its pouvoir constituant directly from the Knesset, but rather as if through the back door. However, although this kind of takeover is describable with the categories taken from Schmitt's philosophy of law, only as their denaturalisation and twisting - Schmitt in his writings directly opposed the institution of judicial activism.

The German jurist had no doubt that the decisions taken by constitutional judges are political in nature, and therefore exceed the powers granted to the judiciary by the separation of powers. In Schmitt's opinion, this was based on the complexity of the cases brought before the Constitutional Court. Because of this complexity, the Court's actions are the creation of law rather than the application of norms. The Constitutional Court is forced to become a legislature in disguise that has nothing to do with the judiciary and stays under the influence of political parties. By assuming the political role, according to Schmitt, the Constitutional Court 'destroys any respect for the constitution and turns the ground of the constitution into an insecure terrain' (Schmitt, 2015, p. 145).

I will not elaborate further on the subject of judicial activism in the context of Schmitt's theory. I have used it only as proof that, although the philosophical, legal and political thought of the author of Constitutional Theory may be an adequate map to describe the territory of Israeli constitutional law, it can only describe its fragments - above all, ones limited temporally. It would be a methodological mistake to regard Schmitt as a thinker whose thought contains material to discuss the entire constitutional history of Israel.

The conclusion is that Carl Schmitt never wrote a word about the State of Israel. The sketch on his work written by Taubes that I quoted at the beginning of this paper was published after his death (it 
was a lecture at the Institute of Philosophy at Free University in West Berlin, where Schmitt was not very welcome, later printed in 'Tageszeitung' on 20 July 1985). It is therefore a mystery whether he knew about Pinchas Rosen and the copy of Constitutional Theory on Mount Scopus or he was aware of the Israeli Declaration of Independence and the acquiring of land by a new state. Nevertheless, Schmitt is useful as the provider of the idiolect to describe what happened in Israel in the late 1940s - although, of course, his thought can be applied only to fragments of legal and political history of that time.

Fragments to which Schmitt's idiolect can be applied include Leo Kohn's three draft versions of the Israeli Constitution, written in the late 1940s, and, as suggested by Jacob Taubes, influenced by Schmitt. Although this influence cannot be determined with absolute certainty, reading the changes made by Kohn in subsequent versions of his draft shows that Schmitt's category of Verfassung more and more appears a useful point of reference for them. Moreover, Schmitt's concept of the nomos can be used to describe the political and legal situation of the 1948 Declaration of Independence - above all the question of leaving Israeli borders open. Although this is a less impressive paradox than the one exposed by Taubes, it remains an impressive paradox nonetheless.

Conflicts of Interest. None

Acknowledgements. I would like to thank Professor Assaf Likhovski from the Buchmann Faculty of Law of Tel Aviv University and Professor Yoram Shachar from Harry Radzyner Law School IDC Herzliya for their valuable comments and help in preparing this paper.

\section{References}

Ben Gurion D (1954) Rebirth and Destiny of Israel. New York: Philosophical Library.

Bickerton I (2009) The Arab-Israeli Conflict. London: Reaktion.

Böckenförde E-W (2017) Constitutional and Political Theory: Selected Writings. Oxford: Oxford University Press.

Burt R (1989) Inventing Judicial Review: Israel and America, Cardozo Law Review 10, 2010-2097.

Cacciari M (2009) The Unpolitical: On the Radical Critique of Political Reason, Verdicchio M (trans.). New York: Fordham University Press.

Elazar DJ (1985) Constitution-making: the Pre-eminently Political Act. In Banting KG and Simeon R (eds), Redesigning the State: The Politics of Constitutional Change. Toronto: University of Toronto Press.

Finchelstein F (2019) From Fascism to Populism in History. Berkeley: University of California Press.

Gerkrath J (2018) Are 'octroyed constitutions' of the 19th century to be considered as imposed constitutions?' In Albert R (ed.), The Law and Legitimacy of Imposed Constitutions. New York: Routledge.

Gross R (2016) Carl Schmitt and the Jews: The 'Jewish Question', the Holocaust, and German Legal Theory, Golb J (trans.). Madison: University of Wisconsin Press.

Gunfello M (2016) Targeted Killing: A Legal and Political History. Cambridge: Cambridge University Press.

Hathaway O and Shapiro SJ (2017) The Internationalists: How a Radical Plan to Outlaw War Remade the World. New York: Random House.

Heidepriem S (2020) Unwritten constitutions: Schmitt, Hegel, and the meaning of Verfassung. German Studies Review 43, 251-270.

Herrero M (2015) The Political Discourse of Carl Schmitt. A Mystic of Order. London/New York: Rowman \& Littlefield.

Hirschl R (2010) Constitutional Theocracy. Boston: Harvard University Press.

Horowitz D and Lissak M (1989) Trouble in Utopia: The Overburdened Polity of Israel. New York: State University of New York Press.

Jabareen H (2019) The paradigm of originalism: Israeli constitutional law and legal thought. Israel Law Review 52, $427-454$.

Jacobsohn G (1992) Apple of Gold: Constitutionalism in Israel and the United States. Princeton: Princeton University Press.

Kalyvas A (2008) Democracy and the Politics of the Extraordinary: Max Weber, Carl Schmitt and Hannah Arendt. Cambridge: Cambridge University Press.

Kedar N (2013) Ben-Gurion's opposition to a written constitution. Journal of Modern Jewish Studies 12, 1-16.

Kedar N (2019) Law and Identity in Israel: A Century of Debate, Watzman H (trans.). Cambridge: Cambridge University Press.

Kelsen H (2017) General Theory of Law and State, Wedberg A (trans.). New York: Routledge.

Kennedy E (2005) Constitutional Failure: Carl Schmitt in Weimar. Durham: Duke University Press.

Kimmerling B (2001) The Invention and the Decline of Israeliness: State, Society and the Military. Berkeley: University of California Press.

Kleiman P (1999) The State of Israel declares independence. The Israel Review of Arts and Letters, 27 April. 
Kohn YL (1954) The Emerging Constitution of Israel. Jerusalem: Israel Office of Information.

Kretzmer D (2019) The Legal Status of the Arabs in Israel. New York: Routledge.

Lerner H (2003) Making Constitutions in Deeply Divided Societies. Cambridge: Cambridge University Press.

Likhovski A (2018) Peripheral vision: Polish-Jewish lawyers and early Israeli law. Law and History Review 36, $235-266$.

Likhovski E (1971) Israel's Parliament, the Law of the Knesset. Oxford: Clarendon Press.

Loewenstein K (1936) Law in the Third Reich. Yale Law Journal 45, 779-815.

Loughlin M (2017) On constituent power. In Dowdle M (ed.), Constitutionalism beyond Liberalism. Cambridge: Cambridge University Press.

Mahler G (2004) Politics and Government in Israel: The Maturation of a Modern State. New York: Rowman \& Littlefield.

Mahler G (2020) The constitutional system of Israel. In Hazan RY (ed.), The Oxford Handbook of Israeli Politics and Society. Oxford: Oxford University Press.

Masri M (2017) The Dynamics of Exclusionary Constitutionalism: Israel as a Jewish and Democratic State. Oxford: Hart Publishing.

McCormick JP (1999) Carl Schmitt's Critique of Liberalism: Against Politics as Technology. Cambridge: Cambridge University Press.

Medding P (1990) The Founding of Israeli Democracy, 1948-1967. Oxford: Oxford University Press.

Mehring R (2014) Carl Schmitt: A Biography, Steuer D (trans.). New York: Polity.

Minca C and Rowan R (2015) The question of space in Carl Schmitt. Progress in Human Geography 3, $268-289$.

Minniken P (2020) Agonism, democracy, and law. In Stern S (ed.), The Oxford Handbook of Law and Humanities. Oxford: Oxford University Press.

Mouffe C (1993) Liberalism and modern decmoracy. In Carens JH (ed.), Democracy and Possessive Individualism. New York: SUNY Press.

Müller J-W (1999) Carl Schmitt's method: between ideology, demonology and myth. Journal of Political Ideologies 4, 61-85.

Müller J-W (2003) A Dangerous Mind: Carl Schmitt in Post-War European Thought. New Haven: Yale University Press.

Murkens J (2013) From Empire to Union: Conceptions of German Constitutional Law since 1871. Oxford: Oxford University Press.

Navot S (2014) The Constitution of Israel: A Contextual Analysis. London: Bloomsbury.

Norris A (1998) Carl Schmitt on friends, enemies and the political. Telos 1998, 68-88.

Oz-Salzberger F and Salzberger E (2000) The secret German sources of the Israel Supreme Court. Tel Aviv University Studies in Law 3, 159-192.

Pan D (2009) Against biopolitics: Walter Benjamin, Carl Schmitt, and Giorgio Agamben on political sovereignty and symbolic order. The German Quarterly 82, 42-62.

Peled Y (2014) The Challenge of Ethnic Democracy: The State and Minority Groups in Israel, Poland and Northern Ireland. New York: Routledge.

Porat I (2017) The platonic conception of the Israeli Constitution. In Dixon R and Stone A (eds), The Invisible Constitution in Comparative Perspective. Cambridge: Cambridge University Press.

Rackman E (1955) Israel's Emerging Constitution, 1948-1951. New York: Columbia University Press.

Radzyner A (2010) Constitution for Israel: the design of the Leo Kohn Proposal, 1948. Israel Studies 15, 1-24.

Radzyner A (2012) The Irish influence on the Israeli Constitution Proposal, 1948. In Carolan E (ed.), The Irish Constitution: Perspectives and Prospects. London: Bloomsbury.

Rae G (2016) The Problem of Political Foundations in Carl Schmitt and Emmanuel Levinas. New York: Palgrave.

Rozin O (2007) Forming a collective identity: the debate over the proposed Constitution, 1948-1950. Journal of Israeli History 26, 251-271.

Salter MG (2012) Carl Schmitt: Law as Politics, Ideology and Strategic Myth. New York: Routledge-Cavendish.

Sapir G, Barak-Erez D and Barak A (2013) Israeli constitutional law at the crossroads. In Sapir G, Barak-Erez D and Barak A (ed.), Israeli Constitutional Law in the Making. Oxford: Hart Publishing.

Schmitt C (1992) Glossarium: Aufzeichnungen der Jahre 1947-1951. Berlin: Duncker \& Humblot.

Schmitt C (2004) Legality and Legitimacy, Seitzer J (trans.). Durham: Duke University Press.

Schmitt C (2005) Political Theology: Four Chapters on the Concept of Sovereignty, Schwab G (trans.). Chicago: University of Chicago Press.

Schmitt C (2006) The Nomos of the Earth in the International Law of Jus Publicum Europaeum, Ulmen GL (trans.). New York: Telos Press.

Schmitt C (2007) The Concept of the Political, Schwab G (trans.). Chicago: University of Chicago Press.

Schmitt C (2008) Constitutional Theory, Seitzer J (trans.). Durham: Duke University Press.

Schmitt C (2015) The guardian of the Constitution. In Vinx L (ed.), The Guardian of the Constitution: Hans Kelsen and Carl Schmitt on the Limits of Constitutional Law. Cambridge: Cambridge University Press.

Schmitt C and Kojève A (2001) Alexandre Kojève-Carl Schmitt correspondence. Interpretation 29, 115-130.

Schneer J (2016) The Balfour Declaration: The Origins of the Arab-Israeli Conflict. New York: Random House.

Schupmann B (2018) Carl Schmitt's State and Constitutional Theory: Critical Analysis. Oxford: Oxford University Press.

Segev T (1986) 1949: The First Israelis, Weinstein A (trans.). New York: Henry Holt. 
Shinar A (2013) Accidental constitutionalism: the political foundations and implications of constitution-making in Israel. In Galligan D (ed.), Social and Political Foundations of Constitutions. Cambridge: Cambridge University Press.

Slomp G (2009) Carl Schmitt and the Politics of Hostility, Violence and Terror. Basingstoke: Palgrave \& Macmillan.

Slováček P (2015) Carl Schmitt and anti-Semitism. Journal of Contemporary European Studies 2, 2-23.

Smooha S (2010) The model of ethnic democracy: response to Danel. Journal of Israeli History 28, 55-62.

Sombart N (1997) Die deutschen Männer und ihre Feinde. Carl Schmitt: ein deutsches Schicksal zwischen Männerbund und Matriarchatsmythos. Berlin: Carl Hanser Verlag.

Stacey R (2011) Constituent power and Carl Schmitt's theory of constitution in Kenya's constitution-making process. International Journal of Constitutional Law 9, 3-4.

Strum P (1995) The road not taken: constitutional non-decision making in 1948-1950. In Troen PI (ed.), Israel: The First Decade of Independence. New York: SUNY Press.

Taubes J (2013) To Carl Schmitt: Letters and reflections, Tribe K (trans.). New York: Columbia University Press.

Troy G (2018) The Zionist Ideas: Visions for the Jewish Homeland Then, Now, Tomorrow. Philadelphia: The Jewish Publication Society.

Tuitt P (2011) International law and the appropriation of the new Europe. In Johns F (ed.), Events The Force of International Law. New York: Routledge.

Walzer M (2016) The Paradox of Liberation: Secular Revolutions and Religious Counterrevolutions. New Haven: Yale University Press.

Weill R (2012) Hybrid constitutionalism: the Israeli case for judicial review and why we should care. Berkeley Journal of International Law 30, 349-411.

Weinrib L (2006) The postwar paradigm and American exceptionalism. In Choudhry P (ed.), The Migration of Constitutional Ideas. Cambridge: Cambridge University Press.

van der Berge L (2019) Law, king of all: Schmitt, Agamben, Pindar. Law and Humanities 13, 198-222.

Vatter M (2021) Living Law: Jewish Political Theology from Hermann Cohen to Hannah Arendt. Oxford: Oxford University Press.

Vermuele A (2009) Our Schmittian administrative law. Harvard Law Review 122, 1095-1150.

Vinx L (2013) Carl Schmitt and the analogy between constitutional and international law: are constitutional and international law inherently political? Global Constitutionalism 2, 91-124.

Voegelin E (1931) Die Verfassungslehre von Carl Schmitt: Versuch einer konstruktiven Analyse ihrer staatstheoretischen Prinzipien. Zeitschrift für Öffentliches Recht 11, 89-109.

Zartaloudis T (2018) The Birth of Nomos. Edinburgh: Edinburgh University Press.

Cite this article: Engelking W (2021). The Jewish Verfassung, the Israeli nomos: the constitutional situation of the beginnings of the State of Israel in the context of Carl Schmitt's political and legal philosophy. International Journal of Law in Context 17, 417-437. https://doi.org/10.1017/S1744552321000483 